\title{
Kazimierz DĄBROWSKI*
}

\section{UNIEJÓW OŚRODKIEM KULTU BLOGOSŁAWIONEGO BOGUMILA}

Zarys treści: W 1668 roku w kolegiacie uniejowskiej zostały złożone doczesne szczątki arcybiskupa gnieźnieńskiego Bogumiła. W 1925 roku Stolica Apostolska ogłosiła Go błogosławionym. W artykule przybliżono postać arcybiskupa Bogumiła, jego życie, przebieg procesu beatyfikacyjnego i trwający nieprzerwanie kult od Jego śmierci po czasy współczesne. Uniejów szczyci się posiadaniem relikwii błogosławionego Bogumiła.

Słowa kluczowe: błogosławiony Bogumił, Dobrów, Uniejów, rozwój kultu, relikwie

\section{ŻYCIORYS BŁOGOSŁAWIONEGO BOGUMIŁA ${ }^{1}$}

Błogosławiony Bogumił urodził się około 1116 roku we wsi Koźminek. Pochodził ze sławnego rodu Porajów (niektórzy uważają, że Bogumił pochodził z rodu Leszczyców lub Pałuków). Rodzicami jego byli Boguchwał - kasztelan gnieźnieński i Katarzyna z domu Gryf. Pragnęli oni dać synom odpowiednie wykształcenie, dlatego wysłali Bogumiła wraz z jego bratem Boguchwałem do

* Ks. Kazimierz Dąbrowski, dr, dyrektor Archiwum Archidiecezjalnego w Łodzi, ul. I. Skorupki 3, 90-458 Łódź, e-mail: archiwum@archidiecezja.lodz.pl.

1 Są dwie teorie odnośnie czasu życia arcybiskupa Bogumiła. Zgodnie z jedną z nich, żył on w XI wieku. W 1075 roku został arcybiskupem gnieźnieńskim mianowanym przez Bolesława Śmiałego. W roku 1076 koronował Bolesława na króla, który musiał ustąpić po konflikcie ze Stanisławem biskupem krakowskim. Po tym konflikcie król Bolesław Śmiały musiał iść na wygnanie, a za jego przykładem poszedł na pustelnię biskup Bogumił. Druga teoria umieszcza Bogumiła w XII wieku i identyfikuje go z arcybiskupem Piotrem. Zob. A. Witkowska, Bogumit bt., [w:] Encyklopedia katolicka, t. 2, red. F. Gryglewicz, R. Łukaszyk, Z. Sułowski, Lublin 1976, s. 722; B. Kumor, Historia Kościoła w Polsce, Poznań-Warszawa 1979, t. 2, cz. 2, s. 262-264; Ś. A. Boleścic-Kozłowski, Czasy świętego Stanisława biskupa krakowskiego i Bolesława Śmiałego króla polskiego, Warszawa 1922, s. 72; T. Wojciechowski, Szkice historyczne jedynastego wieku, Poznań 2004, s. 68; G. Labuda, Szkice historyczne w X-XI wieku. Z dziejów organizacji Kościoła w Polsce we wczesnym średniowieczu, Poznań 2004, s. 366. 
Gniezna, aby tam zdobywali wiedzę od św. Ottona późniejszego biskupa bamberskiego. Studiując w Paryżu znaleźli wzór naśladowania w osobie św. Bernarda - opata cystersów w Clairvaux. Po ukończeniu studiów Boguchwał wstąpił do klasztoru cystersów w Łęknie, Bogumił zaś - po odziedziczeniu po rodzicach dóbr w Dobrowie - wybudował kościół św. Trójcy i postarał się, aby władze kościelne utworzyły parafię².

Arcybiskup gnieźnieński Janisław - wuj Bogumiła wziął go na dwór w Uniejowie, aby pełnił tam funkcję kanclerza i przygotowywał się do święceń kapłańskich. Po święceniach kapłańskich został proboszczem parafii św. Trójcy w Dobrowie, a następnie arcybiskup gnieźnieński mianował go dziekanem katedry gnieźnieńskiej. Pewien czas przebywał w Bieniszewie pod Kazimierzem, jako pustelnik reguły kamedulskiej. W 1167 roku, po śmierci Janisława ${ }^{3}$, kapituła wybrała go arcybiskupem gnieźnieńskim. Jego wybór zatwierdził papież Aleksander III ${ }^{4}$.

Bogumił działał w drugiej połowie XII wieku za rządów Mieszka Starego. Zostając arcybiskupem gnieźnieńskim i metropolitą dla całej Polski, był pierwszą osobą po władcy. Jego działalność duszpasterska przypadła na trudny okres dla Polski, kiedy w wyniku testamentu Bolesława Krzywoustego, nastąpiło rozbicie dzielnicowe, co stało się bezpośrednim powodem do ustawicznych walk między skłóconymi książętami. Bogumił, jako biskup gnieźnieński m.in. zakładał szkoły, aby kształcić dzieci i młodzież. Był zwolennikiem celibatu duchowieństwa, który zaczęto wprowadzać w przepisy Kościoła. Troszczył się o rozwój zakonu cystersów, m.in. wsparł plany brata Boguchwała, aby ufundować klasztor w Węgrowie i ufundował klasztor cystersów w Koronowie. Dokument Władysława Odonica z 1232 roku poświadczył, że arcybiskup Bogumił nadał Dobrów (dobra odziedziczone po rodzicach) cystersom. Dokument ten potwierdza również fakt zapisania swych dóbr rodowych w okolicach Koła na fundację misyjną, która miała kontynuować dzieło św. Wojciecha - nawracanie Prus ${ }^{5}$.

Arcybiskup Bogumił, po pięciu latach kierownictwa archidiecezją gnieźnieńską, w 1170 roku ustąpił ze stanowiska uzyskawszy zgodę papieża Aleksan-

2 Decretum Vladislavien. Confirationis cultus ab immemorabili tempore praestiti Servo Dei Bogumilo Archiepiscopo Gnesnensi Beato vel Sancto nuncupato AAS, „Kronika Diecezji Kujawsko-Kaliskiej, 19, 1925, nr 8, s. 285-286; Rozśpiewaty się dzwony i serca ludzi..., red. A. Urbaniak, Uniejów-Dobrów-Koło-Włocławek 2008, s. 10-11; zob. też, K. Radoński, Święci i błogosławieni kościoła katolickiego. Encyklopedia hagiograficzna, Warszawa-Poznań-Lublin [b.r.m.w.], s. 66.

3 B. Kumor podaje nazwisko arcybiskupa Jan lub Janik. Zob. B. Kumor, Historia Kościoła w Polsce..., s. 262.

${ }_{4}$ Rozśpiewaty się dzwony..., s. 12-13; J. Korytkowski, Arcybiskupi gnieźnieńscy, Poznań 1888, t. 1, s. 262 i n.; Bogumił, [w:] Encyklopedia kościelna, red. W. Nowodworski, Warszawa 1873 , s. 441.

5 T. Wojciechowski, Szkice historyczne.., s. 74; K. Radoński, Święci i błogosławieni Kościoła..., s. 66; [Tysiac] 1000 lat Archidiecezji Gnieźnieńskiej, red. J. Strzelczyk i J. Górny, Gniezno 2000, s. 70. 
dra III. Resztę życia przeżył w pustelni. Zmarł 10 czerwca 1182 roku. Pochowany został w kościele w Dobrowie. Po złożeniu jego ciała do grobu zaczęło tam przybywać wiele osób szukających skutecznej pomocy ${ }^{6}$.

\section{PRZEBIEG PROCESU BEATYFIKACYJNEGO}

Pierwszym krokiem zmierzającym ku beatyfikacji było wydobycie ciała Bogumiła na 50 rocznicę śmierci. Arcybiskup gnieźnieński Pełka w 1257 roku przeniósł doczesne szczątki Bogumiła do specjalnego grobowca i wystawił do publicznej czci. 27 kwietnia 1443 roku arcybiskup Wincenty Kot - ze względu na liczne pielgrzymki do miejsca pochówku Bogumiła zarządził, aby składano ofiary na budowę nowego kościoła w Dobrowie. Po śmierci arcybiskupa Wincentego starania o beatyfikację Bogumiła zostały zawieszone na około dwieście lat. Sprawa ożyła dopiero za arcybiskupa Henryka Firleja, kiedy to kapituła gnieźnieńska zaczęła się domagać beatyfikacji Bogumiła?

W 1623 roku arcybiskup Wawrzyniec Gembicki powołał specjalną komisję, która miała przeprowadzić dochodzenie w sprawie cudów za wstawiennictwem Bogumiła. W 1640 roku arcybiskup Jan Lipski do prac w komisji powołał: archidiakona uniejowskiego - ks. Łukasza Wilkostowskiego, oficjała uniejowskiego - ks. Jakuba Zaborowskiego i Fryderyka Szembeka - jezuitę z kolegium toruńskiego. Przesłuchano również 18 świadków z Uniejowa, Koła i Dobrowa. Przesłuchanie dotyczyło świętości życia i cudów zdziałanych za życia i po śmierci Bogumiłå.

Arcybiskup Maciej Łubieński w 1642 roku zwrócił się do kapituły, by zajęła się relikwiami Bogumiła, a ks. Mateusz Judycki, jako postulator sprawy czynił zabiegi u Stolicy Apostolskiej. Dzięki wspomnianemu arcybiskupowi sprawą Bogumiła zajął się ks. Stefan Damalewicz - prepozyt kanoników regularnych w kościele św. Mikołaja w Kaliszu. Ksiądz Damalewicz był autorem monografii o Bogumile, której pierwsze wydanie ukazało się w 1649 roku. Stefan Damalewicz badał m.in. klasztory cysterskie w Koronowie, Sulejowie i w Łęknie. W Sulejowie znalazł wspomniany wyżej oryginalny dokument Władysława Odonica z 1232 roku. Dowodem troski arcybiskupa Macieja Łubieńskiego było także ufundowanie dla Bogumiła cynowej trumienki i wystawienie jego doczesnych szczątków do publicznej czci9.

${ }^{6}$ Decretum Vladislavien Confirmationis..., s. 288-289; Bogumit, [w:] Encyklopedia Kościelna, s. 441; Rozśpiewały się dzwony..., s. 15; Józef Dobosz przyjmuje, że arcybiskup Bogumił objął godność metropolity po 1180 r. i pełnił ją do około 1190 r., kiedy zrzekł się godności i został pustelnikiem. Zob. Tysiąc lat..., s. 91

7 Bogumit, [w:] Encyklopedia Kościelna..., s. 441: M. Morawski, Błogosławiony Bogumit Arcybiskup Gnieźnieński, „Kronika Diecezji Kujawsko-Kaliskiej” 1925, nr 9, s. 347-352. Błogosławiony Bogumit. Uniejów 1926-2016. W 90. rocznicę uroczystości beatyfikacji, Uniejów 2016, s. 16.

8 Proces beatyfikacyjny $i$ kanonizacyjny Arcybiskupa Bogumiła w XVII wieku wedlug rękopisu Ossolineum 220 II, Wyd. B. Bolz, Poznań 1982, s. 13-15.

9 Tamże, s. 16. 
Dnia 27 września 1647 roku nastąpiło rozpoczęcie procesu beatyfikacyjnego. Najpierw odbyła się wizja lokalna w Dobrowie, która objęła też kościoły w Uniejowie i pałac w Łyszkowicach. Widomymi znakami kultu Bogumiła było ufundowanie kościoła w Dobrowie, w Uniejowie zaś w ołtarzu głównym kolegiaty był obraz patronów Królestwa Rzeczypospolitej, a wśród nich wizerunek Bogumiła. W zamku arcybiskupim w Uniejowie na ścianie Sługa Boży Bogumił był przedstawiony, jako klęczący przed Matką Bożą. Ponadto arcybiskup Łubieński 17 kwietnia 1652 roku mianował Mateusza Judyckiego swym delegatem i pełnomocnikiem do przekazania akt procesowych Kongregacji Świętych Obrzędów ${ }^{10}$.

Sprawą beatyfikacji zainteresował się arcybiskup Wacław Leszczyński. Za jego rządów kapituła gnieźnieńska zadecydowała, aby szczątki doczesne Bogumiła przenieść do katedry gnieźnieńskiej. Podczas gdy w Kurii Rzymskiej zabiegano o beatyfikację Bogumiła kościół modrzewiowy w Dobrowie spłonął, jednak ocalały „relikwie” Bogumiła. Prymas Leszczyński kupił nową trumnę cynową i 14 września 1663 roku po sprawdzeniu tożsamości ułożono trumnę $\mathrm{z}$ relikwiami w kościele dobrowskim, który odbudowano po spaleniu. Po pożarze kościoła w Dobrowie tymczasowo przeniesiono „relikwie” do kolegiaty uniejowskiej. Po odbudowie kościoła szczątki doczesne Bogumiła przeniesiono z powrotem do Dobrowa.

W 1666 roku arcybiskup gnieźnieński Wacław Leszczyński wystawił grobowiec w uniejowskiej kolegiacie, a przeniesienie szczątków Bogumiła nastąpiło 29 stycznia 1668 za prymasa Mikołaja Prażmowskiego (Arcybiskup Leszczyński nie dożył tej uroczystości). Bp Stanisław Dzianott przełożył szczątki do innej skrzyneczki, a następnie opieczętował i oddał delegatowi arcybiskupa i kapituły uniejowskiej ks. Jackowi Justyńskiemu, który zawiózł relikwie do Uniejowa. Delegatami arcybiskupa byli: ks. Mateusz Orłowski sekretarz arcybiskupa i kustosz uniejowski Jacek Justyński ${ }^{11}$.

Prymas Prażmowski wydał edykt, w którym upoważnił biskupów: Jana Bużeńskiego (sufragana gnieźnieńskiego) i Stanisława Dzianotta (sufragana kijowskiego) oraz archidiakona uniejowskiego Jana Grabowskiego do ceremonii, a duchowieństwo dekanatu uniejowskiego, wareckiego i szadkowskiego zachęcał do licznego udziału. Relikwie złożono w marmurowym grobowcu. Uroczystej mszy świętej w Uniejowie przewodniczył biskup Dzianott, a kazanie wygłosił Mateusz Orłowski sekretarz Prymasa ${ }^{12}$.

Autentyczność relikwii została kilkakrotnie potwierdzana. Najpierw za prymasa Mikołaja Prażmowskiego, a następnie za arcybiskupa Stanisława Szembeka (8 lipca 1718 roku) i arcybiskupa Władysława Łubieńskiego (28 lipca 1761 roku). Dnia 10 marca 1780 roku sufragan gnieźnieński złożył „relikwie”

${ }^{10}$ Proces beatyfikacyjny..., s. 18-19; Rozśpiewaty się dzwony..., s. 20.

${ }^{11}$ Uniejów. Dzieje miasta, red. J. Szymczak, Łódź-Uniejów 1995, s. 391; M. Morawski, Błogosławiony Bogumit..., s. 394-395, zob. też J. Żelazek, Inwentarz przedmiotów kultu błogosławionego Bogumiła, „Archiwa, Biblioteki i Muzea Kościelne” 1963, t. 6, s. 228-232.

12 M. Morawski, Błogosławiony Bogumit.., s. 396-397; zob. też Proces beatyfikacyjny..., s. 72. 
do nowych naczyń. Autentyczność ich potwierdził też biskup kujawsko - kaliski Wincenty Chościak-Popiel 10 maja 1882 r. $^{13}$

W 1722 roku stolicę arcybiskupią w Gnieźnie objął arcybiskup Teodor Potocki, który wyznaczył komisję metropolitalną do prowadzenia procesu Sługi Bożego Bogumiła. Komisja składała się z trzech osób: bp Franciszek Kraszkowski (sufragan gnieźnieński), ks. Antoni Krobanowski (kanonik kapituły gnieźnieńskiej) i ks. Michał Kobierzycki (dziekan uniejowski). Komisja ta miała przesłuchać świadków i zebrać wiadomości o cudach za przyczyną Bogumiła. Bulla Urbana VIII z 1634 roku dopuszczała, że jeżeli kult istniał od niepamiętnych czasów, to ma być udowodniony i do tej sprawy wydelegowano 5 maja 1780 roku księdza kanonika Mirowicza ${ }^{14}$.

Sprawę beatyfikacji podjął też prymas Stanisław Szembek. Ufundował on orkiestrę, która grała pieśni na cześć Bogumiła. Dnia 5 listopada 1741 roku ustanowiono kantorów, którzy śpiewali hymn o Bogumile. W 1749 roku na polecenie arcybiskupa Antoniego Krzysztofa Szembeka zaczęto prowadzić księgę, gdzie spisywano otrzymane łaski i składane wota. W 1759 roku kapituła uniejowska poleciła odmawiać litanię o Bogumile. Do Dobrowa i Uniejowa przybywały pielgrzymki z Włocławka, Płocka i Częstochowy. Szczególnie uroczyście obchodzono dzień Bogumiła 10 czerwca. Wyrazem czci dla Bogumiła było nadawanie często dzieciom tego imienia. Dnia 23 czerwca 1788 roku kapituła uniejowska prosiła prymasa Poniatowskiego, aby zajął się sprawą beatyfikacji. Dalszym staraniom beatyfikacyjnym przeszkodzily rozbiory Polski. Kult Bogumiła w Uniejowie osłabł, a po zniesieniu kapituły w 1819 roku przez władze carskie, miał odtąd tylko charakter lokalny ${ }^{15}$.

W 1902 roku bp Stanisław Zdzitowiecki zlecił proboszczowi parafii uniejowskiej w latach 1894-1911 ks. Tomaszowi Bukowskiemu gromadzić materiały i zapisywać cuda, a w 1903 roku wyznaczył komisję w sprawie kultu Bogumiła, która składała się z siedmiu osób. Sędzią został ks. prałat Stanisław Chodyński. Funkcję sędziów asystentów objęli: ks. prałat Franciszek Stopieżyński i proboszcz uniejowski Tomasz Bukowski; postulatorem sprawy beatyfikacyjnej z ramienia Biskupa Ordynariusza został ks. prałat Karol Maks; promotorem fiscalis został ks. kanonik Stanisław Mirecki; urzędowym notariuszem do sporządzenia kopii i sprawdzenia zeznań świadków - ks. prałat Wojciech Owczarek, a ks. Feliks Jaroszewski - wikariusz parafii uniejowskiej został cursor nuntius. Oprócz wymienionych osób komisja zaprosiła dwóch znawców sztuki - Konstantego i Jarosława Wojciechowskich, którzy mieli wydać sąd o pamiątkach i zabytkach kultu odnoszących się do Bogumiła. Zrobiono wyciągi z dokumentów i archiwaliów kapitulnych z Uniejowa, Włocławka i Gniezna. Prace komisji trwały do 1909 roku i stwierdzono cały szereg cudów oraz łask. Sędzia Chodyński ogłosił,

\footnotetext{
${ }^{13}$ M. Morawski, Blogosławiony Bogumit..., s. 398 i n.

14 Tamże, s. 455-457.

${ }_{15}$ M. Morawski, Błogostawiony Bogumił..., s. 18, s. 399 i 401; Rozśpiewaty się dzwony..., s. 20; Btogostawiony Bogumit..., s.16 i n.
} 
że cześć Bogumiła trwała od niepamiętnych czasów i trwa nieprzerwanie oraz nie podlega bulli Urbana VIII z 1634 r. Wyrok przewodniczącego ks. Chodyńskiego został potwierdzony 20 listopada 1909 roku przez biskupa Zdzitowieckiego i pisma te wysłano w 1910 roku do Kongregacji Świętych Obrzędów ${ }^{16}$.

W dniach 11 listopada 1912 roku i 31 stycznia 1913 roku wyszły nowe przepisy Stolicy Apostolskiej domagające się zbadania pism Sługi Bożego - czy nie są przeciwne wierze? Ponieważ nie odnaleziono dokumentów, wobec tego 29 sierpnia 1919 roku bp Zdzitowiecki wniósł prośbę do Stolicy Apostolskiej o prowadzenie procesu mimo braku pism Bogumiła. W Rzymie nad tą sprawą czuwał ks. Józef Florczak audytor Roty Rzymskiej. Dnia 11 sierpnia 1920 roku wydano Dekret Kongregacji Obrzędów potwierdzony przez papieża Benedykta XV; Dekret zawierał dyspensę od pism i możliwość prowadzenia procesu bez tej dokumentacji ${ }^{17}$.

19 maja 1925 roku w Watykanie na posiedzeniu Kongregacji Obrzędów został potwierdzony wyrok, że Bogumił może być błogosławionym. Beatyfikacja nastąpiła 27 maja 1925 roku, której dokonał papież Pius XI ${ }^{18}$.

\section{KULT BOGUMIŁA W UNIEJOWIE W LATACH 1925-2016}

W końcu 1925 roku tymczasowy rządca diecezji biskup Wojciech Owczarek pochodzący z Uniejowa zajął się obchodami dziękczynnymi za beatyfikację. Powołał komitet, w ramach którego powstały trzy sekcje: a) informacyjna, b) finansów i c) kwaterunku pielgrzymów. W ramach tej działalności wydano broszurę pod tytułem Żywot błogosławionego Bogumiła w nakładzie 20 tys. egzemplarzy. Uroczystości odbyły się w dniach 22-24 maja 1926 roku i były połączone z uroczystością Zesłania Ducha Świętego. Nie wypadły one okazale jak się spodziewano, bowiem przewrót majowy spowodował sparaliżowanie komunikacji. Do Uniejowa przyjechało tylko trzech biskupów (bp Wincenty Tymieniecki, bp Stanisław Łukomski i bp Stanisław Krynicki) oraz cztery delegacje kapituł katedralnych: lwowskiej. łomżyńskiej, łódzkiej i włocławskiej, a także kapituła kolegiacka z Kalisza. W uroczystościach wzięło udział 90 kapłanów i 90 tys. wiernych. Dnia 22 maja relikwie bł. Bogumiła przeniesiono procesyjnie do kościoła Bożego Ciała, a następnie do świątyni pokolegiackiej, gdzie odczytano dekret Stolicy Apostolskiej, a uroczystą sumę celebrował bp Stanisław Łukomski. W tym samym czasie na rynku uniejowskim odprawił mszę świętą bp Wincenty Tymieniecki. W ostatni dzień obchodów uroczystą mszę św. odprawił bp Władysław Krynicki, a kazanie wygłosił bp Tymieniecki. Po sumie celebrowanej przez bpa Tymieniec-

\footnotetext{
${ }^{16}$ M. Morawski, Btogostawiony Bogumit.., s. 450-451.

17 Tamże, s. 460-461.

${ }^{18}$ Decretum Vladislavien..., s. 285-298; M. Morawski, Błogostawiony Bogumit..., s. 452; Rozśpiewały się dzwony..., s. 21; Uniejów. Dzieje miasta, s. 396.
} 
kiego część relikwii bł. Bogumiła przeniesiono i złożono w kościele w Dobrowie (w tej uroczystej celebrze wziął udział bp Wojciech Owczarek i 50 księży) ${ }^{19}$.

7 września 1931 roku ordynariusz włocławski - bp Karol Radoński zezwolił, aby w niedzielę po uroczystości Bogumiła były wystawione jego relikwie do publicznej czci. W 1932 roku w siedemsetpięćdziesięciolecie śmierci bł. Bogumiła odbyły się w Dobrowie uroczystości jubileuszowe, w których wziął udział kardynał August Hlond, a także bp Antoni Laubnitz z Gniezna, Wincenty Tymieniecki z Łodzi, Karol Radoński z Włocławka i sufragan włocławski Wojciech Owczarek oraz stu księży ${ }^{20}$.

8 września 1939 roku nastąpiło bombardowanie kolegiaty uniejowskiej przez wojska III Rzeszy; świątynię uszkodzono i sprofanowano relikwie bł. Bogumiła. Pod gruzami kościoła uniejowskiego relikwie ocalały, a 14 października 1946 roku bp Karol Radoński stwierdził ich autentyczność ${ }^{21}$.

W latach 1946-1980 w Uniejowie widać przejawy kultu Bogumiła m.in. poprzez odprawianie nabożeństw w każdą środę, podczas których były śpiewane pieśn i litania do tego Błogosławionego oraz publiczne ucałowanie Jego relikwii. Wierni zanosili prośby, które były proklamowane przez kapłana odprawiającego to nabożeństwo. Troskę o kult Bogumiła w Uniejowie wykazywali też ordynariusze włocławscy bp Antoni Pawłowski i bp Jan Zaręba ${ }^{22}$.

31 maja 1982 roku obchodzono centralne uroczystości jubileuszowe 800-lecia śmierci błogosławionego Bogumiła patrona diecezji włocławskiej; z tej okazji nadesłał list papież Jan Paweł II ${ }^{23}$.

Dnia 16 grudnia 1990 roku ordynariusz włocławski bp Henryk Muszyński wznowił kapitułę uniejowską na cześć Najświętszej Maryi Panny Wniebowziętej, św. Józefa i bł. Bogumiła mianując prepozytem ks. prałata Stanisława Smolarskiego. 16 czerwca 1999 roku Kongregacja do Spraw Kultu Bożego i Sakramentów ogłosiła bł. Bogumiła patronem miasta Koło. Kolejnym przejawem kultu bł. Bogumiła było utworzenie 5 października 2005 roku przez biskupa Wiesława Meringa parafii bł. Bogumiła w Kole. 28 grudnia 2006 roku ordynariusz włocławski ustanowił sanktuarium w Dobrowie. W tymże roku z inicjatywy władz samorządowych został wzniesiony w Uniejowie pomnik Bogumiła (co roku odbywa się procesja z relikwiami do tego pomnika) ${ }^{24}$.

Po reelekcji Kapituły każdego roku odbywa się posiedzenie generalne kapituły uniejowskiej pod przewodnictwem biskupa Wiesława Meringa, w święto Matki Kościoła, natomiast w Dobrowie odpust ku czci Bogumiła jest obchodzony 10 czerwca (czynione są starania, aby kapituła uniejowska miała generalne

${ }^{19}$ Rozśpiewaty się dzwony..., s. 20-22.

${ }^{20}$ Uniejów. Dzieje miasta..., s. 396; Rozśpiewaty się dzwony..., s. 22-23.

${ }^{21}$ Uniejów. Dzieje miasta..., s. 409; Błogosławiony Bogumit..., s. 22.

22 Błogostawiony Bogumit..., s. 26.

${ }^{23}$ Jan Paweł II, List Ojca świętego z racji jubileuszu 800-lecia śmierci bt. Bogumiła, „Kronika Diecezji Włocławskiej” 1982, t. 65, nr 5-6, s. 103-104.

${ }^{24}$ „Kronika Diecezji Włocławskiej”, 2005, t. 88, nr 11-12, s. 649-650; Uniejów. Dzieje miasta, s. 413; Rozśpiewały się dzwony..., s. 100 i n.; Błogostawiony Bogumit... 
posiedzenie w uroczystość Bogumiła). Obecny prepozyt kapituły uniejowskiej ksiądz infułat Andrzej Ziemieśkiewicz sprawił, że nad relikwiami czuwają Rycerze Zamkowi i zamierza sprowadzić do Uniejowa Rycerzy Kolumba ${ }^{25}$.

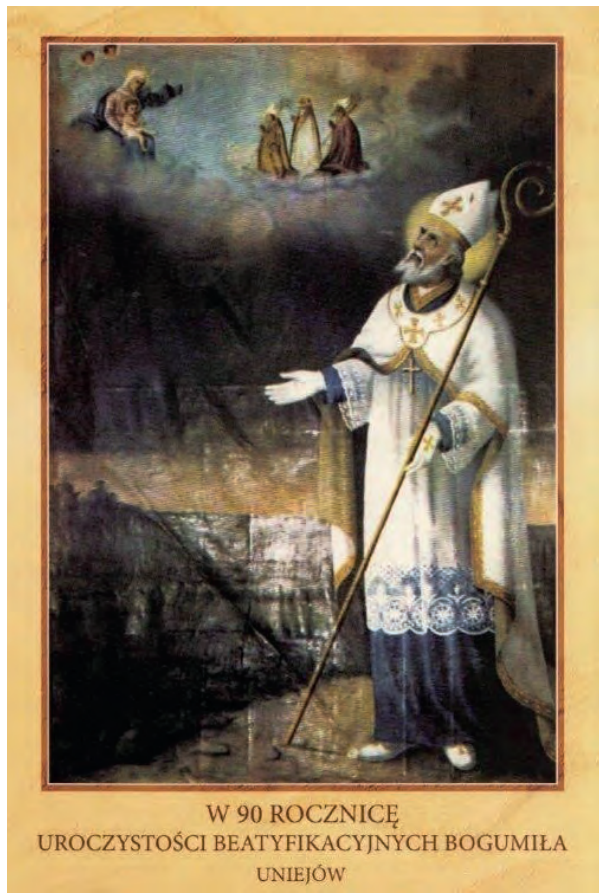

Ryc. 1. Pamiątkowy obrazek z obchodów 90. rocznicy uroczystości beatyfikacyjnych Źródło: Parafia Uniejów

Kapituła uniejowska przekazała relikwie Bogumiła do Koła (2007), Poznania (2009), Studzionki (2012) i Bydgoszczy (2015). Obecnie relikwie błogosławionego Bogumiła znajdują się w kolegiacie uniejowskiej w trzech relikwiarzach: ołowianym, srebrnym i będącym w skarbcu kolegiaty; są one celem licznych pielgrzymek ${ }^{26}$.

\section{Bibliografia}

\section{Dokumenty Stolicy Apostolskiej i Biskupów Diecezjalnych}

Decretum Vladislavien. Confirmationis cultus ab immemorabili tempore praestiti Servo Dei Bogumilo Archiepiscopo Gnesnensi Beato vel Sancto nuncupato, „Kronika Diecezji Kujawsko-Kaliskiej" 1925, t. 19, nr 8.

${ }^{25}$ Błogostawiony Bogumit...; Relacja ks. Andrzeja Ziemieśkiewicza.

${ }^{26}$ Diecezja Włocławska 2000, oprac. W. Frątczak, W. Kujawski i in., Włocławek 2001, s. 626; Btogostawiony Bogumit..., s. 26. 
Diecezja Włocławska 2000, oprac. W. Frątczak, W. Kujawski i in., Włocławek 2001.

Jan Paweł II, List Ojca świętego z racji jubileuszu 800-lecia śmierci błogosławionego Bogumiła, „Kronika Diecezji Włocławskiej” 1982, t. 65, nr 5-6.

Zaręba J., Słowo pasterskie na 800-lecie śmierci błogosławionego Bogumiła drugiego patrona diecezji, „Kronika Diecezji Włocławskiej” 1982, t. 65, nr 5-6.

\section{Opracowania}

Błogosławiony Bogumił. Uniejów 1926-2016. W 90 rocznicę uroczystości beatyfikacji, Uniejów 2016.

Bogumit, [w:] Encyklopedia kościelna, t. 2, red. W. Nowodworski, Warszawa 1873.

Boleścic-Kozłowski Ś. A., Czasy świętego Stanisława biskupa krakowskiego i Bolesława Śmiałego króla polskiego, Warszawa 1922.

Cerski R., Bt. Bogumił sławny cudotwórca, Włocławek 2002.

Cyranowski J., Żywot bt. Bogumiła, Poznań 1926.

Głowacki P., Duchowi spadkobiercy bt. Bogumiła, „Ład Boży” 1998, nr 23.

Korytkowski J., Arcybiskupi gnieźnieńscy, t. 1, Poznań 1888.

Kumor B., Historia Kościoła w Polsce, t. 2, cz. 2. Poznań-Warszawa 1979.

Labuda G., Szkice historyczne w X-XI wieku. Z dziejów organizacji Kościoła w Polsce we wczesnym średniowieczu, Poznań 2004.

Morawski M., Błogosławiony Bogumił Arcybiskup Gnieźnieński, „Kronika Diecezji Kujawsko-Kaliskiej” 1925, t. 19, nr 9.

Proces beatyfikacyjny i kanonizacyjny Arcybiskupa Bogumiła w XVII wieku wedtug rękopisu Ossolineum 220 II, Wyd. B. Bolz, Poznań 1982.

Radoński K., Święci i błogosławieni Kościoła Katolickiego, Encyklopedia hagiograficzna, Warszawa-Poznań-Lublin [b.r.m.w].

Strzelczyk J., Górny J. (red.), [Tysiąc]1000 lat Archidiecezji Gnieźnieńskiej, Gniezno 2000.

Szymczak J. (red.), Uniejów. Dzieje miasta, Łódź-Uniejów 1995.

Urbaniak A. (red.), Rozśpiewały się dzwony i serca ludzi..., Uniejów-Dobrów-Koło-Włocławek 2008.

Witkowska A., Bogumił bt., [w:] Encyklopedia Katolicka, t. 2, red. F. Gryglewicz, R. Łukaszyk, Z. Sułowski, Lublin 1976.

Wojciechowski T., Szkice historyczne jedenastego wieku, Poznań 2004.

Żelazek J., Kult bt. Bogumiła, Lublin 1973.

Żelazek J., Inwentarz przedmiotów kultu błogosławionego Bogumiła, „Archiwa, Biblioteki i Muzea Kościelne" 1963, t. 6.

[Artykuł wpłynął: maj 2017; zaakceptowany: czerwiec 2017] 


\section{UNIEJÓW - THE CULT CENTER OF BLESSED BOGUMIŁ}

\section{Summary}

In 1668 in the collegiate church in Uniejów were placed the mortal remains of archbishop of Gniezno, Bogumił. In 1925 the Holy See pronounced him blessed. This article acquaints the readers with the personality and life of archbishop Bogumił and describes his beatification process and cult since his death up to the present. Uniejów is proud to have the relics of blessed Bogumił.

Keywords: blessed Bogumił, Dobrów, Uniejów, development of the cult, relics 